Review

\title{
Insights into Nuclear G-Protein-Coupled Receptors as Therapeutic Targets in Non-Communicable Diseases
}

\author{
Salomé Gonçalves-Monteiro ${ }^{1,2}$, Rita Ribeiro-Oliveira ${ }^{1,2}$, Maria Sofia Vieira-Rocha ${ }^{1,2}$, Martin Vojtek ${ }^{1,2} \mathbb{1}$, \\ Joana B. Sousa ${ }^{1,2, *}$ and Carmen Diniz ${ }^{1,2, *(\mathbb{D})}$ \\ 1 Laboratory of Pharmacology, Department of Drug Sciences, Faculty of Pharmacy, University of Porto, \\ 4050-313 Porto, Portugal; salomemonteiro8180@gmail.com (S.G.-M.); ritarmo23@gmail.com (R.R.-O.); \\ msrocha@ff.up.pt (M.S.V.-R.); matovoj@gmail.com (M.V.) \\ 2 LAQV/REQUIMTE, Faculty of Pharmacy, University of Porto, 4050-313 Porto, Portugal \\ * Correspondence: jbsousa@ff.up.pt (J.B.S.); cdiniz@ff.up.pt (C.D.)
}

check for

updates

Citation: Gonçalves-Monteiro, S.; Ribeiro-Oliveira, R.; Vieira-Rocha, M.S.; Vojtek, M.; Sousa, J.B.; Diniz, C. Insights into Nuclear G-ProteinCoupled Receptors as Therapeutic Targets in Non-Communicable Diseases. Pharmaceuticals 2021, 14, 439. https://doi.org/10.3390/ph14050439

Academic Editors: Erika Cione and Maria Cristina Caroleo

Received: 26 March 2021

Accepted: 30 April 2021

Published: 7 May 2021

Publisher's Note: MDPI stays neutral with regard to jurisdictional claims in published maps and institutional affiliations.

Copyright: (c) 2021 by the authors. Licensee MDPI, Basel, Switzerland. This article is an open access article distributed under the terms and conditions of the Creative Commons Attribution (CC BY) license (https:/ / creativecommons.org/licenses/by/ $4.0 /)$.

\begin{abstract}
G-protein-coupled receptors (GPCRs) comprise a large protein superfamily divided into six classes, rhodopsin-like (A), secretin receptor family (B), metabotropic glutamate (C), fungal mating pheromone receptors (D), cyclic AMP receptors (E) and frizzled (F). Until recently, GPCRs signaling was thought to emanate exclusively from the plasma membrane as a response to extracellular stimuli but several studies have challenged this view demonstrating that GPCRs can be present in intracellular localizations, including in the nuclei. A renewed interest in GPCR receptors' superfamily emerged and intensive research occurred over recent decades, particularly regarding class A GPCRs, but some class B and C have also been explored. Nuclear GPCRs proved to be functional and capable of triggering identical and/or distinct signaling pathways associated with their counterparts on the cell surface bringing new insights into the relevance of nuclear GPCRs and highlighting the nucleus as an autonomous signaling organelle (triggered by GPCRs). Nuclear GPCRs are involved in physiological (namely cell proliferation, transcription, angiogenesis and survival) and disease processes (cancer, cardiovascular diseases, etc.). In this review we summarize emerging evidence on nuclear GPCRs expression/function (with some nuclear GPCRs evidencing atypical/disruptive signaling pathways) in non-communicable disease, thus, bringing nuclear GPCRs as targets to the forefront of debate.
\end{abstract}

Keywords: GPCRs; cancer; cardiovascular diseases; ligands; nuclear GPCR signaling; GPCRbased therapeutics

\section{Introduction}

G-protein-coupled receptors (GPCRs) comprise a large and versatile protein superfamily known to mediate responses to several extracellular stimuli namely small molecules, peptides and proteins, photons, etc., that regulate a broad spectrum of physiological functions, such as vision, smell and taste. GPCRs also modulate neurological, cardiovascular, endocrine and reproductive functions [1-4]. GPCRs regulatory actions have justified the past and current intensive research in the development of GPCR ligands and their applicability and use in different economic sectors of society.

Based on the knowledge gathered so far, GPCR ligands are being used to generate products with commercial value for diverse types of industries such as pharmaceutical, food and cosmetic. Some of these products take advantage of GPCRs' properties as cell communication modulators in physiological processes involving the sensorial system. Examples of that are the taste and smell [5-7]. Accordingly, some GPCR ligands can be incorporated into products to ameliorate their sensorial properties and, consequently, improve their acceptability by consumers. Furthermore, some studies also indicate that certain GPCRs can mediate sweet-taste synergisms (for instance, sweeteners, neohesperidin dihydrochalcone and cyclamate), which can potentiate the response of cells to sucrose, [8] 
providing a way to reduce sugar content in food. Taking advantage of this knowledge, several studies are currently undergoing with the view to develop sugar substitutes for a healthy diet, which has a major impact on human life and well-being. This subject has been the focus of intense research in the last few years and is particularly important for patients with metabolic diseases.

Another group of GPCR ligands has been designed with the goal to treat or prevent diseases that involve, for instance, the cardiovascular, nervous or endocrine systems. In this regard, GPCRs are targets for nearly 35\% of the drugs currently in use in clinical practice [9], and comprise more than 100 types of receptors [10] divided into six classes according to the following classification [11,12]: rhodopsin-like (A), secretin receptor family (B), metabotropic glutamate (C), fungal mating pheromone receptors (D), cyclic adenosine monophosphate (cAMP) receptors (E) and frizzled (F), where classes $D$ and $E$ are not found in vertebrates.

Ligands can act to promote GPCRs activation (agonists) or, by opposition, to block the activity exerted by GPCRs (neutral antagonists or inverse agonists). Currently, ligands for GPCR mainly belong to rhodopsin-like receptors ( $94 \%$ ), and from these, the aminergic receptors constitute the group with more receptor types. These ligands include antagonists (that block the receptors' activity induced by endogenous ligands, namely hormones, neurotransmitters, among others), but also agonists (full, partial and inverse agonists) which are able to activate and modulate GPCR responses, being used for specific therapeutic applications. Intense research focusing on the development of new GPCR-based therapeutics, using for example crystallography, biosensors [13-15] or computational chemistry [16] have allowed the appearance of a new generation of drugs, some of them revisiting older targets, but others are looking for ligands that do not bind directly to the ligand binding pocket. Examples are inverse agonists, allosteric modulators and drugs targeting GPCR heterodimers. As a consequence, an increasing number of patents on GPCR ligands are currently under evaluation concerning its value/safety in clinical trials involving several types of diseases (please see as an example [17]). During the past decade, drug repositioning studies have extended the therapeutic indications of many drugs currently in use in clinical practice including drugs that bind to GPCRs $[1,18,19]$.

Activation of plasma membrane GPCRs usually is mediated by the binding of an agonist that stabilizes the active conformation of the receptor with the subsequent recruitment and activation of intracellular signaling pathways [20]. Indeed, when GPCRs are activated, receptors may couple to several heterotrimeric $G$ proteins, namely $G \alpha_{i / o}, G \alpha_{q / 11}, G \alpha_{12 / 13}$ and $G_{\beta \gamma}$, to regulatory proteins such as $G$ protein-coupled receptor kinases (GRKs) and $\beta$-arrestins, and then activate downstream signaling pathways [21,22]. Moreover, dimerization activation, transactivation, biased activation, biphasic activation, and intracellular activation of GPCR have also been recently described as forms of activation of GPCRs, increasing the complexity of the GPCR activation processes (for more information on this subject, please see [2,23]).

Classically, GPCRs are considered as cell surface receptors with seven-transmembrane domains localized in the plasma membrane but scientific data revealed that a large number of GPCRs are also present in intracellular sites, including in the nuclei (e.g., in the nuclear membrane), the nuclear GPCRs. These receptors seem to have an important biological impact and gained interest due to their putative role in the regulation of gene transcription, both in physiology and in disease, namely in non-communicable diseases. In this review we focus on the most recent findings related to nuclear GPCRs expression and function demonstrating the biological relevance of GPCRs localized in the nuclear membrane, particularly in non-communicable diseases, where atypical and disruptive signaling events have been reported, thus highlighting nuclear GPCRs as new therapeutic targets to the forefront of debate. In addition, GPCR ligands and the development of strategies to selectively discriminate the newly identified nuclear GPCRs will also be discussed. 


\section{Nuclear GPCRs in Physiological Conditions}

In 1971, Robertson and Kijairallah provided the first sign indicative of a new localization for GPCRs [24], by injecting angiotensin II (Ang II) in a nuclear zone and observing ultrastructural changes. Consequently, a renewed interest had led to an intensive research in this field and to a shift from a dogmatic view that considered GPCRs as functional receptors exclusively present in the plasma membrane, to a view that appoints for the existence of GPCRs in intracellular compartments [1,25-27]. Indeed, in initial studies, the intracellular localization of GPCRs was interpreted as a way of receptor traffic within the cell (from the nuclei to membrane or vice versa) but findings showing an intracellular localization of GPCRs [28] that have a functional role [1,25] have extended the way GPCRs are now viewed.

Nuclear GPCRs seem to have a widespread distribution in the organism, and reports have shown their occurrence particularly in the cardiovascular and nervous system, although their presence has also been described in the nuclear membrane of cells from other anatomical regions such as liver, kidney, cornea and bones [27,29]. The presence of GPCRs in the nuclear membrane has been established experimentally in culture cells (Human embryonic kidney (HEK-293), Mouse melanoma (B16) and Chinese hamster ovary (CHO) cells, cardiomyocytes, vascular smooth muscle cells, neurons, among others type of cells) but also in tissue cells from animal models (heart, hypothalamus, thalamus, septum, midbrain, liver, kidney and spleen [27]). In these studies, the nuclear localization of GPCRs has been identified both in isolated nuclei or intact cells using radioligand binding assays, electron and/or confocal microscopy techniques and western blot [30]. In addition to morphological studies, the actions exerted by nuclear GPCRs have been assayed using methods that enable to segment the nuclear GPCRs' activation (relatively to respective plasma membrane counterparts), involving, for instance, cytosolic microinjections [30], caged and/or photolyzed ligands [31].

It has been established that GPCRs can be found in the nuclear envelope, at the inner and/or outer membranes, positioned in a way that allows the effector-binding domain to face the cytosol or the nucleoplasm [32]. The way GPCRs appear in the nuclear membrane seems to occur in many ways, as previously reviewed [27,33,34]. Briefly, GPCRs might be synthesized in the endoplasmic reticulum or within the nucleus, and then traffic to the nuclear membrane constituting nuclear GPCRs. Another possible source for nuclear GPCRs is the internalization of plasma membrane GPCRs and their subsequent translocation into the nuclear membrane via an agonist-dependent pathway [1]. Interestingly, some reports also indicate that GPCRs translocation from plasma to nuclear membrane can also occur upon activation via an agonist independent pathway (please see [27]). Moreover, short peptide sequences of basic amino acid residues (usually lysine/glycine-arginine repeats) present in the $C$ terminus or in the intracellular loop of GPCRs, have been identified as nuclear localization sequences (NLS) [35] and these sequences appear to be involved in the translocation of GPCRs to the nucleus. NLS motif seems to orientate GPCRs to the nucleus through importin mechanisms and/or small GTPases [34,36]. On the other hand, the translocation process can also be independent of the NLS motif, with some receptors such as bradykinin type 2 (B2) (although presenting a NLS sequence) requiring heterodimerization with lamin C [37] to translocate to the nuclear membrane. In addition, some other sequences of peptides (different from the classical NLS) can also foment the nuclear import of receptors as observed with the 38 amino acid long fragment of heterogeneous nuclear ribonucleoproteins $\mathrm{A} 1$ and $\mathrm{A} 2$ proteins (the $\mathrm{M} 9$ sequence) that can be recognized by transportin [27].

It is important to emphasize that the GPCRs that have been identified in the nuclear membrane mostly belong to class A GPCRs, from where 22 receptor families and 34 GPCR subtypes have been described in a nuclear localization. In addition, some receptors belonging to class B (two families and three subtypes), class C (two families and three subtypes) and class $\mathrm{F}$ (one family and one subtype) have also been identified in the nuclear membrane [27]. 
The way nuclear GPCRs can be activated still needs further studies in order to clarify if its behavior is aligned with that described for plasma membrane GPCRs. Nevertheless, studies conducted so far indicate that the classical activation mediated by ligands and subsequent activation of signaling pathways described for plasma membrane GPCRs seems to also occur in nuclear GPCRs. Indeed, innumerable studies support that in physiological conditions nuclear GPCRs activation (and subsequent events) occurs within the nucleus by pathways involving second messengers, ion channels, proteins, etc., that are commonly associated with plasma membrane GPCRs [1,30,38,39]. In this sense, GPCRs localized in the nuclear membrane can trigger and modulate nuclear calcium levels, cAMP generation, nitric oxide (NO) and/or reactive oxygen (ROS) and/or nitrogen species (RNS) production, which, in turn, will condition the regulation of gene transcription and, thus, of multiple physiological processes, namely of cell proliferation, transcription, apoptosis, angiogenesis and survival $[1,31,37]$. Overall, these data highlight the nucleus as an autonomous signaling organelle containing functional nuclear GPCRs.

\section{Nuclear GPCRs Activation: Endogenous and Exogenous Ligands}

The complete knowledge regarding the way nuclear GPCRs are activated still needs further studies but a large amount of data describes that activation of nuclear GPCRs results from the interaction of the receptor with exogenous or endogenous ligands. Endogenous ligands are synthesized in the organism, in other cell types or within the cell itself (Figure 1). The later process appears to occur intracellularly and increases the ligand bioavailability near the nucleus in order to activate nuclear GPCRs. As such, the intracellularly produced ligands seem to constitute the preferential candidates to bind to nuclear GPCRs. Examples of that type of ligands are apelin, bradykinin, Ang II [40] and prostanoids [41] including prostaglandins, platelet-activating factor lysophosphatidic acid [42] and endothelin [43]. For another type of ligands, namely extracellular ligands (both exogenous and endogenous), their bioavailability to interact with nuclear GPCRs depends largely on their respective ability to cross the plasma membrane and, thus, access nuclear GPCRs: ligands that are lipophilic molecules may freely trespass the plasma membrane and reach the nucleus (by diffusion), whereas for ligands with less plasma membrane permeability (with more hydrophilic properties), its uptake requires alternative ways such as endocytosis or transport through membrane exchangers and/or transporters (for example: glutamate [40], urotensin-II [44], etc.).

Despite efforts regarding the development of new GPCR ligands in the last decades, few studies have focused on the selectivity and/or affinity towards nuclear GPCRs. Some ligands produced to activate plasma membrane GPCRs have been tested regarding its capability to interact with GPCRs localized in the nuclear membrane. Examples of that are Ang II and Losartan, an agonist and antagonist, respectively, that have been used with success to modulate nuclear angiotensin type $1\left(\mathrm{AT}_{1}\right)$ receptors localized in the nuclear membrane of dopaminergic neurons [45], as well as in the kidney of normotensive and hypertensive Lewis rats [46] Interestingly, some $\mathrm{AT}_{1}$ receptor antagonists such as Candesartan seem to have an effect mostly on the $\mathrm{AT}_{1}$ receptors localized in the plasma membrane while other antagonists such Losartan have shown to block plasma membrane $\mathrm{AT}_{1}$ receptors as well as nuclear $\mathrm{AT}_{1}$ receptors [47]. Such behavior demonstrates that $\mathrm{AT}_{1}$ receptor antagonists seem to present differential selectivity between plasma and nuclear membrane receptors. Isoproterenol is another ligand that has been described to bind to a receptor localized in the nuclear membrane, the nuclear $\beta_{3}$ adrenoceptor in rat cardiomyocytes [48]. Other nuclear GPCRs, such as nuclear urotensin-II [49] and nuclear B2 [50] receptors, have also been blocked by antagonists that were developed to target their respective plasma membrane counterparts. Despite this evidence, an extended and detailed study is still needed to characterize and clarify the selectivity and affinity of all currently known drugs that use GPCRs as targets towards nuclear GPCRs. Such characterization would allow the identification of drugs/ligands capable of discriminating 
nuclear GPCRs towards their respective plasma membrane counterparts and, therefore, be more target-directed.

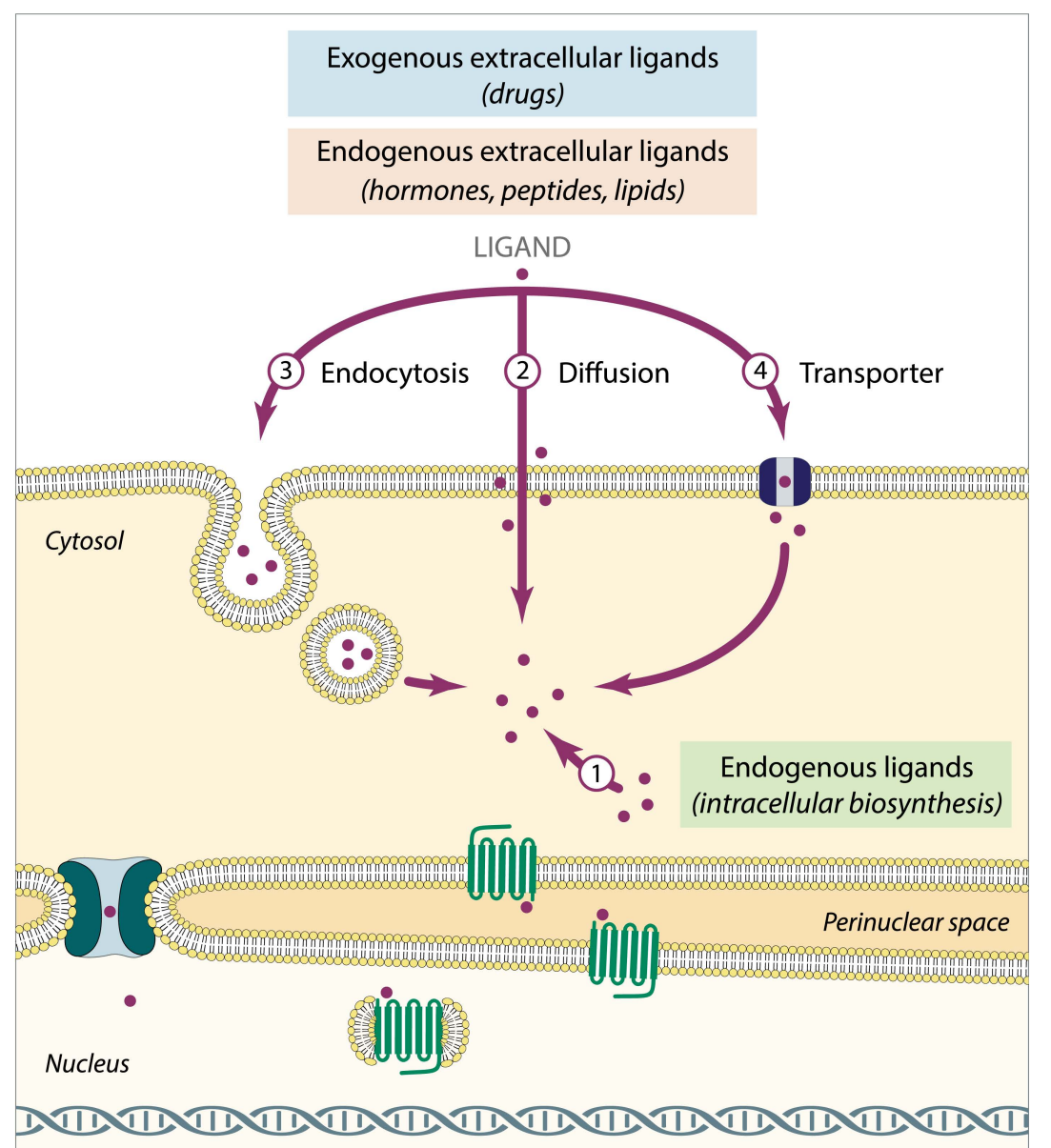

Figure 1. Activation of nuclear G-protein-coupled receptors (GPCRs). Exogenous and endogenous (extracellular and intracellularly produced): (1) biosynthesis of endogenous ligands inside the cell; (2) diffusion of extracellular ligands; (3) endocytosis of extracellular ligands; (4) active transport of extracellular ligands (transporters and exchangers).

Recent findings regarding the critical influence of lipid composition/structure in the conformational states of GPCRs are also valuable information for the rational design of molecules with the view of obtaining selective ligands for nuclear GPCRs. Medicinal chemistry and the design of new molecules with removable functional groups that allow a higher cell-permeability [51] directing the molecular functional core to the nucleus is another possible strategy to obtain selective nuclear GPCR ligands. These strategies, despite presenting the advantage of delivering the ligand into an intracellular localization and, therefore, turning it to be capable of activating nuclear GPCRs, cannot rule out the putative concomitant activation of respective plasma membrane GPCRs counterparts.

Another possible approach to obtain ligands with an improved selectivity towards nuclear GPCRs relies on the rational design of ligands with allosteric sites, but the application of allosteric binding can be a problem for intracellular sites (reducing ligand specificity as previously described [52]). To overcome these difficulties, the ligand (agonist or antagonist) needs to be designed in a way that ensures a higher affinity and increased binding capabilities for nuclear GPCRs among with the requirement of being able to cross the plasma membrane entering the cell and be diffused into the cytosol, and then, traffic to the nucleus [51]. To address this, ligands (new or already on the market) could be incorporated into nanoparticles [53] or peptides [54,55] which would allow its uptake into cells by taking advantage of cell biological processes (endocytosis and/or exchanger and/or transporters) 
allowing the putative interaction between the ligand and the targeted nuclear GPCR. As so, a strategy to ensure the target selectivity for nuclear GPCRs may rely, for example, on the use of ligands inside a carrier that is sensitive to intracellular enzymes localized near the nucleus, allowing the delivery of the ligands as pro-drugs into an intracellular environment nearby the nucleus. Thus, ligands that selectively target nuclear GPCRs will constitute valuable tools for researchers to further investigate the mechanisms triggered by nuclear GPCRs and of its ultimate effects. Further studies are also needed to improve or create tools/methods that could enhance the knowledge regarding nuclear GPCRs as targets incrementing the development of ligands that present selectivity for these receptors.

\section{Nuclear GPCRs in Non-Communicable Diseases}

Lipid composition and/or the structure of cell membranes are known to play crucial roles in several cell trafficking and signaling pathways, participating also in the maintenance of homeostasis. As so, lipid composition and/or cell membrane structural changes or lipid imbalance are crucial aspects that can influence the pathophysiological processes that, subsequently, lead to disease [56,57], and may interfere, at least in part, with the way nuclear GPCRs are expressed and function. Such types of phenomena have also been described to occur with other proteins, namely with sphingomyelin and with functional proteins of the nuclear lipid microdomains in cancer cells that increased shuttling of protein signaling molecules [58]. It is also important to highlight the crucial role of lipid composition and/or the structure of cell membranes in the conformational state of GPCRs: any alteration in receptor conformation may modify the receptor binding "pocket" altering the way GPCRs are expected to function. In accordance, it has been shown that negatively charged lipids can stabilize the active state of receptors such as $\beta_{2}$-adrenoceptors, enabling the docking of $G_{\alpha s}$ protein while neutral zwitterionic lipids seem to inactivate the receptor [59]. Therefore, the GPCRs localized in the nuclear membrane may also be influenced by these phenomena and be involved in the pathophysiology and development of noncommunicable diseases $[60,61]$. Moreover, scientific data also indicate the occurrence of constitutively active mutations in GPCRs that have been associated with diseases [62,63], which can also have a role in the pathophysiological processes.

Regardless of these aspects, studies conducted in cell lines as well as in animal models of diseases appointed for the occurrence of an abnormal expression and/or function of some nuclear GPCRs in pathological conditions associated with non-communicable diseases (Table 1). A redistribution of GPCRs within the cell can occur in healthy state and disease: for instance, in standard metabolic conditions, nuclear parathyroid hormone receptor type 1 (PTH1) and plasma membrane PTH1 revealed a similar expression while in metabolic deprivation conditions, an increase in the nuclear localization of this receptor type occurred contrasting to the reported reduction of plasma membrane PTH1; other examples of GPCRs redistribution (from the plasma membrane to nuclei and vice versa) are shown in Table 2. Interestingly, it has been observed that changes in GPCRs expression, namely the redistribution of receptors from the plasma membrane to nuclear membrane can lead to differential functions of the receptor (Table 2). Moreover, depending on the pathological condition considered, alterations in nuclear GPCRs expressions have also been reported with the occurrence of an upregulation of some type of nuclear GPCRs while in other conditions a downregulation has been reported. Accordingly, the changes in nuclear GPCRs expression depend on the type of pathology as depicted in Table 1. Furthermore, some reports have demonstrated that in specific pathologies, some nuclear GPCRs transduction pathways are deregulated or disruptive, evidencing alterations in the expression and function of the receptor itself and/or of respective signaling mediators. In addition, reports also demonstrated that in diseases such as cardiovascular diseases and cancer some nuclear GPCRs when activated can trigger atypical signaling mediators, therefore, triggering pathways that are not commonly associated with that particular GPCR [64]. 
Table 1. Nuclear GPCRs occurrence in non-communicable diseases.

\begin{tabular}{|c|c|c|c|c|c|}
\hline Pathology & Type/Sample & Model & Nuclear GPCR & Effectors/Mediators and/or Effects & Ref \\
\hline \multirow[t]{18}{*}{ Cancer } & \multirow{4}{*}{ Lung } & Human non-small-cell lung cancer & CXCR4 & & [65] \\
\hline & & Human non-small-cell lung cancer tissue & $\uparrow \mathrm{CXCR} 4$ & associated with a better outcome & [66] \\
\hline & & $\begin{array}{l}\text { Human primary non-small cell } \\
\text { lung cancer tissue }\end{array}$ & CXCR4 & $\begin{array}{c}\text { aberrant nuclear CXCR4 expression } \leftrightarrow \\
\text { lymph node metastasis }\end{array}$ & [67] \\
\hline & & Human lung carcinoma cell line & FPR2 & Gai-ERK2, c-Jun and c-Myc phosphorylation & [35] \\
\hline & Liver & Human hepatoma cancer cells & CXCR4 & - & [68] \\
\hline & \multirow{2}{*}{ Prostate } & Human prostate cancer cell lines & $\uparrow \mathrm{CXCR4}$ & G $\alpha \mathrm{i}-\uparrow \mathrm{Ca} 2+; \uparrow$ nuclear CXCR4 with tumor grade & [70] \\
\hline & & Human prostate cancer cell lines & GPR158 & promotes cell proliferation & [71] \\
\hline & Oral & Nasopharyngeal carcinoma & CXCR4 & associated with the cancer progression & [72] \\
\hline & Colon & Human colon adenocarcinoma cell line & VPAC & & [30] \\
\hline & \multirow[b]{2}{*}{ Colorectal } & \multirow[b]{2}{*}{ Human colorectal cancer tissue } & $\uparrow \mathrm{CXCR} 4$ & associated with poor overall survival & [73] \\
\hline & & & $\uparrow \mathrm{CXCR} 4$ & nuclear CXCR4 - more frequent lymph node metastasis & [74] \\
\hline & Placenta & Human placental choriocarcinoma cell lines & MT2 & - & [75] \\
\hline & Bone & $\begin{array}{c}\text { Human osteosarcoma (U2OS, MG63, } \\
\text { OS15 and SaOS2) }\end{array}$ & OT & - & [76] \\
\hline & \multirow{5}{*}{ Breast } & $\begin{array}{l}\text { Human breast carcinoma cell lines } \\
\text { (T47D, MDAMB-468) }\end{array}$ & $\uparrow \mathrm{VPAC}_{1}$ & Gos- $\uparrow \mathrm{cAMP}$ & [77] \\
\hline & & Human breast cancer (MCF7) & OT & - & [76] \\
\hline & & Human ductal carcinoma tissue & CXCR4 & - & [78] \\
\hline & & \multirow[b]{2}{*}{ Human triple-negative breast cancer } & $\uparrow B_{1}$ & $\begin{array}{l}\text { cell-permeable antagonists have superior } \\
\text { antineoplastic activity }\end{array}$ & [79] \\
\hline & & & $\uparrow B_{2}$ & $\begin{array}{l}\text { cell-permeable antagonists have superior antineoplastic } \\
\text { activity; anti-proliferative effects through } \\
\text { p38kinase/p27Kip1 }\end{array}$ & [80] \\
\hline
\end{tabular}


Table 1. Cont.

\begin{tabular}{|c|c|c|c|c|c|}
\hline Pathology & Type/Sample & Model & Nuclear GPCR & Effectors/Mediators and/or Effects & Ref \\
\hline & \multirow{3}{*}{ Brain } & $\begin{array}{l}\text { Human glioblastoma- } \\
\text { astrocytoma U87-MG and human } \\
\text { neuroblastoma SH-SY5Y cell lines }\end{array}$ & UT & transcription initiation & [49] \\
\hline & & Glioblastoma multiforme cell lines & CXCR4 & - & [81] \\
\hline & & Glioblastoma multiforme cell lines & $\uparrow \mathrm{VPAC}_{1} \mathrm{VPAC}_{2}$ & $\uparrow$ nuclear VPAC1 with glioma grade & [82] \\
\hline & \multirow{3}{*}{ Gastric } & $\begin{array}{l}\text { Human gastric adenocarcinoma tissue } \\
\text { and cell line }\end{array}$ & CXCR4 & nuclear CXCR4 expression $\leftrightarrow$ better overall survival & [83] \\
\hline & & Primary gastric cancer tissue & CXCR4 & nuclear CXCR4 expression $\leftrightarrow$ reduced survival rate & [84] \\
\hline & & Human gastric adenocarcinoma cell line & FPR2 & Gai-ERK2, c-Jun and c-Myc phosphorylation & [35] \\
\hline & \multirow{3}{*}{ Renal } & \multirow{3}{*}{ Human renal carcinoma cell lines } & CXCR4 & in the nucleus only in metastatic lesions & [85] \\
\hline & & & CXCR4 & $\begin{array}{l}\text { interaction and nuclear accumulation of } \\
\text { HIF- } 1 \alpha-\text { metastasis promotion }\end{array}$ & [86] \\
\hline & & & CXCR4 & $\begin{array}{l}\text { interaction with myosin heavy chain-IIA-CXCR4 } \\
\text { nuclear translocation- } \uparrow \text { tumor metastatic capacity }\end{array}$ & [78] \\
\hline \multirow[t]{7}{*}{ Cardiovascular Diseases } & Inflammation & Rat cardiomyocytes & $\beta$ & $\begin{array}{c}\text { G } \alpha \mathrm{i}-\mathrm{PI} 3 \mathrm{~K}-\mathrm{PKB}-\mathrm{ERK} 1 / 2-\downarrow \mathrm{NF}-\mathrm{kB} \\
\text { transcription- } \downarrow \text { ATF-2, IL1r1 and Tnfrsf1b }+\uparrow \text { Ripk2 } \\
\text { transcription } \rightarrow \text { suppression of inflammatory response }\end{array}$ & [88] \\
\hline & \multirow{2}{*}{ Hypertension } & Hypertension model—rat kidney & $\downarrow \mathrm{AT}_{1}$ & - & [89] \\
\hline & & Fetal programming model—sheep kidney & $\uparrow \mathrm{AT}_{1}, \downarrow \mathrm{AT}_{2}$ & $\uparrow \mathrm{ROS}, \downarrow \mathrm{NO}$ & [90] \\
\hline & Heart failure & $\begin{array}{l}\text { Heart failure model—canine cardiac } \\
\text { fibroblasts }\end{array}$ & $\uparrow \mathrm{AT}_{1}$ & $\begin{array}{l}\text { AT1-IP3- } 1 \mathrm{Ca} 2+- \text { regulate fibroblast proliferation, } \\
\text { collagen gene expression and collagen secretion }\end{array}$ & [31] \\
\hline & \multirow{3}{*}{ Angiogenesis } & Human umbilical vein endothelial cells & $\mathrm{S}_{1} \mathrm{P}_{1}$ & Cyr61 and CTGF expression & [91] \\
\hline & & $\begin{array}{l}\text { Model of oxygen-induced } \\
\text { retinopathy—rat ocular tissue }\end{array}$ & PAF & $\begin{array}{l}\text { VEGF-dependent neovascularization in } \\
\text { oxygen-induced retinopathy }\end{array}$ & [92] \\
\hline & & Mouse retinal ganglion cells & F2rl1 & $\begin{array}{l}\text { Sp1 recruitment- } \uparrow \text { VEGF } \alpha \\
\text { expression } \rightarrow \text { neovascularization }\end{array}$ & [93] \\
\hline
\end{tabular}


Table 1. Cont.

\begin{tabular}{|c|c|c|c|c|c|}
\hline Pathology & Type/Sample & Model & Nuclear GPCR & Effectors/Mediators and/or Effects & Ref \\
\hline \multirow[t]{3}{*}{$\begin{array}{l}\text { Neurological and } \\
\text { neurodegenerative diseases }\end{array}$} & Neuropathic pain & Rat spinal dorsal horn neurons & $\uparrow \mathrm{mGlu}_{5}$ & $\begin{array}{l}\text { Nerve injury- }-\uparrow \text { nuclear mGlu5- }-\uparrow[\mathrm{Ca} 2+] \mathrm{n}+\text { ERK1/2 } \\
\text { and Arc/Arg3.1 activation }+\uparrow \text { c-fos expression }\end{array}$ & [94] \\
\hline & Nociceptive & Rat spinal dorsal horn neurons & $\uparrow \mathrm{mGlu}_{5}$ & Inflammation- $\uparrow$ nuclear mGlu5- $\uparrow \mathrm{c}$-fos expression & [95] \\
\hline & Oxidative stress & Rat and dopaminergic neurons cell line & $\mathrm{AT}_{1}, \mathrm{AT}_{2}$ & $\begin{array}{c}\text { AT1-IP3- } \uparrow \mathrm{Ca} 2+\rightarrow \uparrow \mathrm{AT} 2+\text { Ang }+ \text { PGC- } 1 \alpha+\text { IGF-1 } \\
\text { transcription } \rightarrow \text { cellular protection; } \\
\text { AT1-NOX4- } 1 \text { superoxide } / \mathrm{H} 2 \mathrm{O} 2 \rightarrow \text { antioxidant } \\
\text { response; AT2-NOS- } \uparrow \mathrm{NO}\end{array}$ & [45] \\
\hline
\end{tabular}

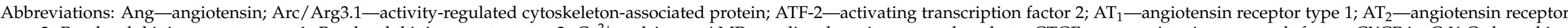

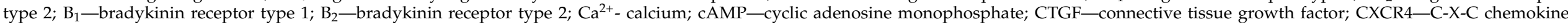

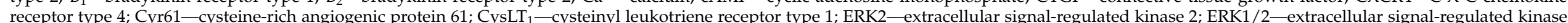

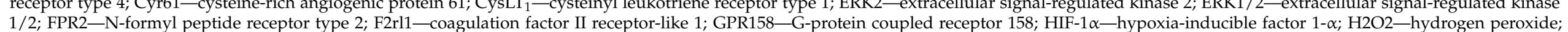

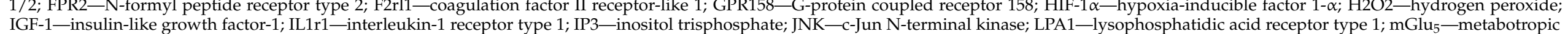

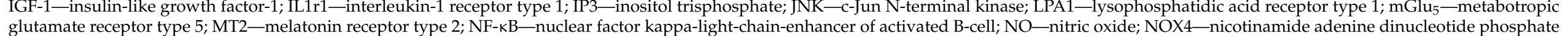

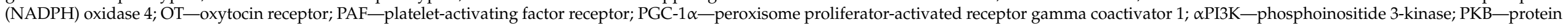

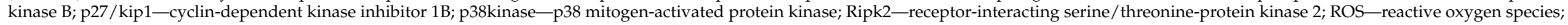

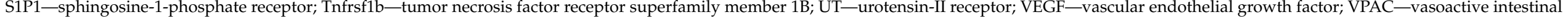
peptide receptor; $\mathrm{VPAC}_{1}$-vasoactive intestinal peptide type 1 receptor; $\mathrm{VPAC}_{2}$-vasoactive intestinal peptide type 2 receptor. 
As so, targeting such nuclear GPCRs may constitute promising and innovative approaches to treat/prevent these diseases. In the following sections, a summary of the most recent findings regarding the expression and function of GPCRs localized in the nuclear membrane in cancer, neurological and neurodegenerative diseases and cardiovascular diseases will be described.

\subsection{Nuclear GPCRs in Cancer}

In several cancer types, an upregulation of nuclear GPCRs has been observed as shown for the nuclear vasoactive intestinal peptide type $1\left(\mathrm{VPAC}_{1}\right)$ receptor (gliomas [82]; breast cancer [77]) and for the nuclear C-X-C chemokine type 4 (CXCR4) receptor (non-small-cell lung cancer [66]). Nuclear $\mathrm{VPAC}_{1}$ receptors upregulation has been proposed to be involved in a mechanism of tumor resistance [82] while nuclear CXCR4 receptors expression has been associated with cancer prognosis. Nuclear CXCR4 receptors were associated with a better outcome in an early-disease stage in non-small-cell lung cancer [66] while for nasopharyngeal carcinoma [72], renal carcinoma [85,86,97], colorectal cancer [73] and gastric cancer [84], the nuclear expression of CXCR4 receptors seems to be linked with poor survival and an increased metastatic capacity. In fact, in nasopharyngeal carcinoma, nuclear CXCR4 receptors could be used as a prognostic factor since the association between cancer progression and poor overall survival has been previously reported [64]. Likewise, regarding colorectal cancer, nuclear but not cytoplasmic expression of this receptor was associated with advanced cancer and lymphovascular invasion [73]. For renal carcinoma, nuclear CXCR4 receptors persistently demonstrated to be a promoter of metastasis $[78,85,86]$ and the receptor's localization at the nuclear membrane was only found in metastatic renal cell carcinoma lesions [85].

Changes in the signaling pathways triggered by nuclear GPCRs have been identified in cancer (Table 1) with the occurrence of increased levels of signaling mediators and of protein phosphorylation. An atypical activity ascribed to nuclear GPCRs activation has been reported: activation of some nuclear GPCRs has been shown to trigger different signaling events and pathways relatively to those commonly described for the respective plasma membrane GPCRs. As such, these GPCRs and respective pathways can be viewed as putative targets presenting a promising role in cancer therapy (Figure 2).

In accordance with this, the modulation of nuclear $B_{2}$ receptors with cell-permeable antagonists (for this type of receptor) proved their involvement in human triple-negative breast cancer via a mechanism involving p38 mitogen-activated protein kinase (p38 kinase) — cyclin-dependent kinase inhibitor $1 \mathrm{~B}\left(\mathrm{p} 27^{\mathrm{kip} 1}\right)$ leading to apoptosis and reducing cell proliferation [80]. Thus, nuclear $\mathrm{B}_{2}$ receptors may constitute a promising target that when inhibited can reduce cancer progression. Moreover, other GPCR, the N-formylpeptide type 2 (FPR2) receptor was described to be expressed at a nuclear level in lung carcinoma, triggering intranuclear signaling that leads to enhanced extracellular signalregulated kinase 1/2 signaling (ERK1/2), c-Jun and c-Myc phosphorylation, and therefore, affecting cell cycle, apoptosis and cell proliferation [39].

Another report described that the orphan receptor, probable G-protein coupled 158 (GPR158) receptor promotes prostatic cell proliferation (in human prostate cancer cells) independently of androgen receptor function and stimulates androgen receptors and prostate specific antigen expression. Simultaneously, an alternative mechanism, consistent with the localization of these receptors in the nuclei of cells, promoting cell proliferation is activated [71], thus the GPR158 receptors blockade may reduce cell proliferation and cancer development. Moreover, in cancer, namely in colorectal adenocarcinomas, activation of nuclear cysteinyl leukotriene type $1\left(\mathrm{CysLT}_{1}\right)$ receptor seems to trigger proliferative ERK1/2 contributing to inflammation-induced colon carcinogenesis [38]. As so, inhibition of nuclear CysLT $_{1}$ receptors can also constitute a putative strategy to reduce carcinogenesis and lead to a better treatment outcome in colon carcinoma. 


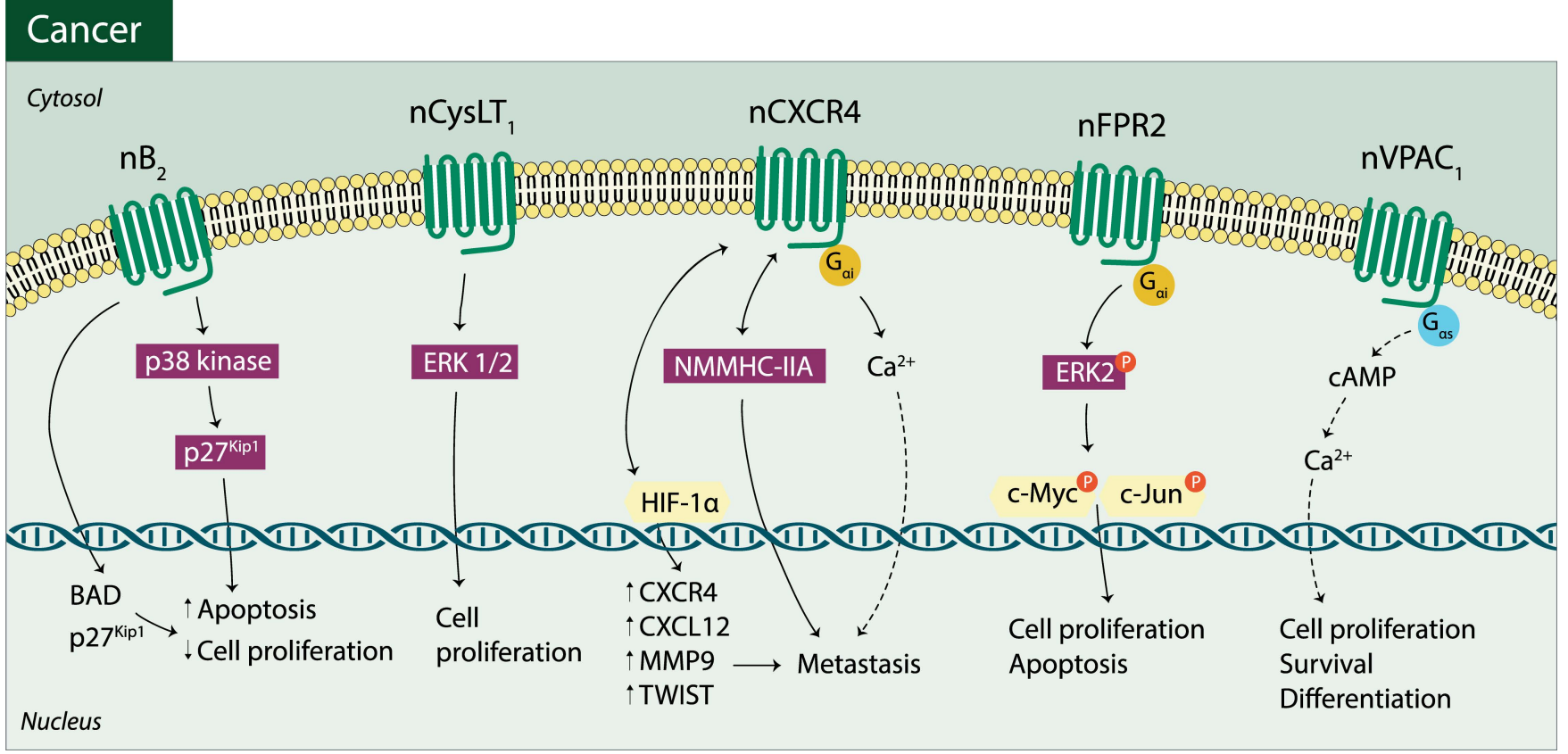

Figure 2. Atypical pathways involving nuclear GPCRs in cancer: nuclear bradykinin B type 2 (nB ${ }_{2}$ ), nuclear cysteinyl leukotriene type 1 (nCysLT 1 ), nuclear C-X-C chemokine type 4 (nCXCR4), nuclear N-formyl peptide type 2 (nFPR) and nuclear vasoactive intestinal peptide type $1\left(\mathrm{nVPAC}_{1}\right)$ receptor activated signaling pathways.

Table 2. Differential expression between nuclear and plasma membrane GPCRs in physiological and pathophysiological conditions.

\begin{tabular}{|c|c|c|c|c|}
\hline Receptor & Nuclear Membrane & Plasma Membrane & Cell Type/Function & Ref. \\
\hline \multirow[t]{2}{*}{$\mathrm{mGlu}_{5}$} & + & ++ & Striatal neurons & [98] \\
\hline & & & growth/differentiation & \\
\hline \multirow[t]{2}{*}{ mGlu $_{5}$} & ++ & ++ & Striatal neurons & [98] \\
\hline & & & $\begin{array}{l}\text { synaptic plasticity and } \\
\text { growth/differentiation }\end{array}$ & \\
\hline \multirow[t]{2}{*}{$\mathrm{mGlu}_{5}$} & + & ++ & $\begin{array}{l}\text { spinal dorsal } \\
\text { horn neurons }\end{array}$ & [94] \\
\hline & & & without pain & \\
\hline \multirow[t]{2}{*}{$\mathrm{mGlu}_{5}$} & +++ & ++ & $\begin{array}{l}\text { spinal dorsal } \\
\text { horn neurons }\end{array}$ & [94] \\
\hline & & & persistent pain & \\
\hline \multirow[t]{2}{*}{ S1P1 } & & ++ & unstimulated T-cells & [99] \\
\hline & & & $>$ cell migration & \\
\hline \multirow[t]{2}{*}{ S1P1 } & +++ & + & Stimulated T-cells & [99] \\
\hline & & & $<$ cell proliferation & \\
\hline \multirow[t]{2}{*}{ F2rl1 } & & ++ & Vascular cells & [93] \\
\hline & & & $>$ vessel maturation & \\
\hline \multirow[t]{2}{*}{ F2rl1 } & +++ & ++ & Vascular cells & [93] \\
\hline & & & >angiogenesis & \\
\hline
\end{tabular}


Table 2. Cont.

\begin{tabular}{ccccc}
\hline Receptor & Nuclear Membrane & Plasma Membrane & Cell Type/Function & Ref. \\
\hline PTH1 & ++ & ++ & Osteoblasts & {$[36,100]$} \\
\hline & & & Standard metabolism \\
\hline PTH1 & +++ & ++ & Osteoblasts & {$[36,100]$} \\
\hline & & & Metabolic deprivation \\
\hline
\end{tabular}

Abbreviations: F2rl1-coagulation factor II receptor-like 1; mGlu - metabotropic glutamate type 5 receptor PTH1 - parathyroid hormone type 1 receptor; S1P1—sphingosine-1-phosphate receptor. definition amount of receptors: +, low; ++, middle; +++, high.

\subsection{Neurological and Neurodegenerative Diseases}

Evidence also demonstrates the occurrence of nuclear GPCRs-mediated mechanisms in neurological and neurodegenerative diseases (Figure 3). High levels of Ang II were reported to increase oxidative stress and to promote neuroinflammation [101] and, in dopaminergic neurons, had led to an overexpression of nuclear $\mathrm{AT}_{1}$ receptors while the expression of nuclear angiotensin type $2\left(\mathrm{AT}_{2}\right)$ receptors was downregulated [45].

\section{Neurological diseases}

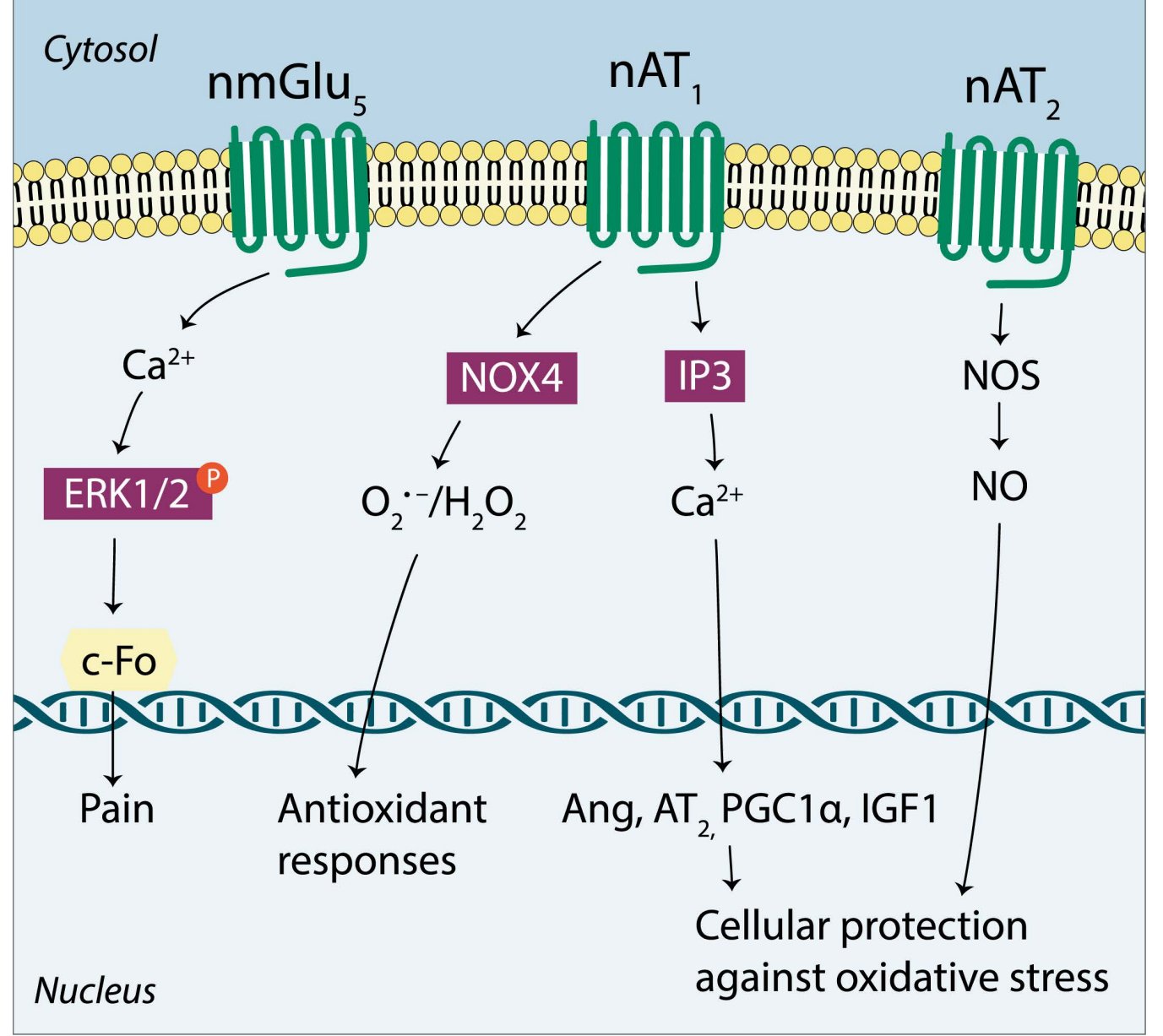

Figure 3. Atypical pathways involving nuclear GPCRs in neurological and neurodegenerative diseases: nuclear metabotropic glutamate type $5\left(\mathrm{nmGLU}_{5}\right)$, nuclear angiotensin type 1 (nAT 1 ) and type $2\left(\mathrm{nAT}_{2}\right)$ receptor activated signaling pathways. 
Activation of nuclear $\mathrm{AT}_{1}$ receptors by Ang II has been described to trigger protective mechanisms involving, for instance, increase levels of peroxisome proliferator-activated receptor gamma coactivator 1-alpha (PGC-1 $\alpha$ ) and insulin-like growth factor 1 (IGF-1)sirtuin 1 (SIRT1) [45] modifying mitochondria biogenesis/function. Since the nervous system depends on ATP levels for the maintenance of ionic gradients across the cell membranes and for neurotransmission, improvement of mitochondria biogenesis has a substantial beneficial impact on neuronal function and, thus explains why nuclear $\mathrm{AT}_{1}$ receptor can be protective in nervous system diseases.

Another effect of nuclear GPCRs in the nervous system has also been described in spinal dorsal neurons where an upregulation of nuclear metabotropic glutamate type $5\left(\mathrm{mGlu}_{5}\right)$ receptors occurred resulting in ERK1/2 activation as well as into an activityregulated cytoskeleton-associated protein (Arc/Arg3.1) activation, causing an upregulation of c-fos expression [95] and, thus, evidencing a critical role for nuclear $\mathrm{mGlu}_{5}$ receptors in neuropathic pain. In the literature, it has been described that in persistent pain, in spinal dorsal horn neurons, most of $\mathrm{mGlu}_{5}$ receptors are localized intracellularly in the nucleus where they are functionally active [94].

Furthermore, it has been observed that during aging the nuclear distribution and responses of GPCRs can also present considerable changes since evidence indicates a decrease in nuclear $\mathrm{AT}_{1}$ and nuclear $\mathrm{AT}_{2}$ receptors in aged brains, accompanied by an impairment of several compensatory mechanisms contributing to the neurodegenerative processes associated with aging [45].

All the nuclear GPCRs above described constitute, therefore, putative therapeutic targets that need to be further studied in neurological and neurodegenerative diseases.

\subsection{Cardiovascular Diseases}

In several cardiovascular diseases, modifications in the expression of the GPCRs localized in the nuclei membrane were also described [29]. For example, an upregulation was found in nuclear $\mathrm{AT}_{1}$ receptors in heart failure [31] and in fetal programming of hypertension induced by glucocorticoids [90] while, by opposition, a downregulation of nuclear $\mathrm{AT}_{1}$ receptors was observed in hypertension [89]. Furthermore, the nuclear $\mathrm{AT}_{2}$ receptors expression in fetal programming of hypertension [90] has been demonstrated to be downregulated.

In addition, an altered activity exerted by nuclear GPCRs has also been described in cells from the cardiovascular system contributing to disease (Figure 4). For instance, in heart failure, nuclear $\mathrm{AT}_{1}$ receptors have led to an increase in nuclear $\mathrm{Ca}^{2+}$ having an impact both in the subsequent regulation of fibroblast proliferation and in the collagen gene expression/secretion [31]. Moreover, in fetal programming of hypertension, nuclear $\mathrm{AT}_{1}$ receptors have been described to be activated and to mediate an increase in ROS generation as well as a decrease of $\mathrm{NO}[46,90]$. Both effects involve the $\mathrm{AT}_{1}$ receptors localized in the nuclear membrane and seem to contribute to an increase in blood pressure.

Moreover, nuclear GPCRs atypical activity has also been described associated with the nuclear $\beta$-adrenoceptors (nuclear $\beta_{1}$ and/or nuclear $\beta_{3}$ subtypes) that may also interact with endothelin (ET-1), modulating transcription factors generation (Figure 4). Activation of nuclear $\beta_{1}$ and/or nuclear $\beta_{3}$ adrenoceptors seems to cause a reduction of nuclear factor kappa-light-chain-enhancer of activated B-cell (NF-kB), an activation of transcription factor 2 (ATF-2), of the interleukin-1 type 1 (IL1r1) receptor and an increase of tumor necrosis factor receptor superfamily member 1B (Tnfrsf1b) transcription in inflammation related with congestive heart failure and atrial fibrillation [88].

These GPCRs may constitute putative targets that should be considered for some (already identified) cardiovascular diseases. 


\section{Cardiovascular diseases}

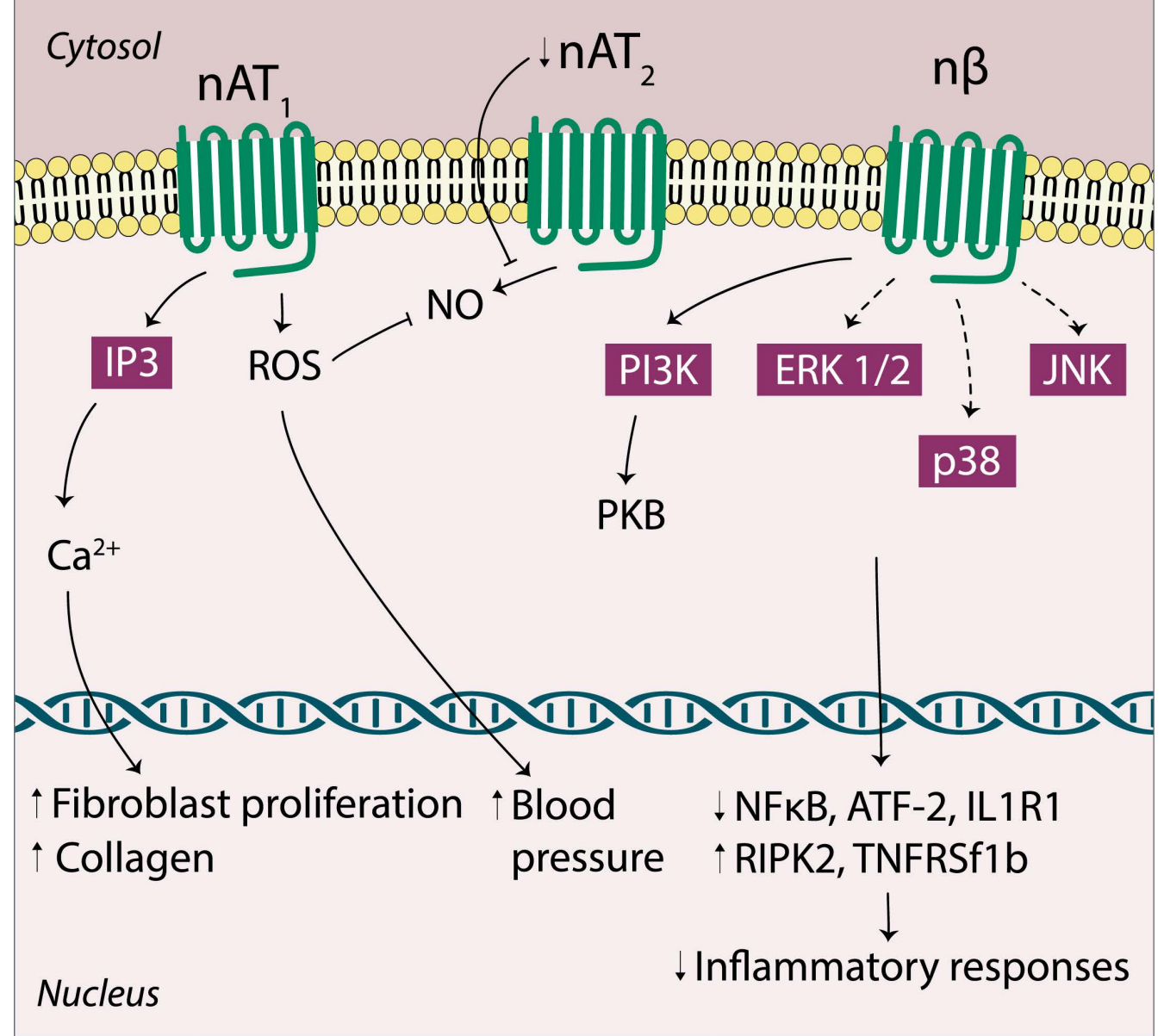

Figure 4. Atypical pathways involving nuclear GPCRs in cardiovascular diseases: $\mathrm{nAT}_{1}$ and $\mathrm{nAT}_{2}$ receptor and nuclear $\beta$-adrenoceptor $(\mathrm{n} \beta)$ activated signaling pathways in cardiovascular diseases.

\section{GPCR-Based Drugs in the Treatment of Non-Communicable Diseases: Implication of Nuclear GPCRs as Targets}

Most drugs currently in use in clinical practice to treat and/or prevent several types of diseases namely non-communicable diseases, are GPCR-based drugs. The occurrence of nuclear GPCRs as new targets is supported by recent data that has identified several atypical mechanisms and altered signaling pathways triggered by GPCRs localized in the nuclear membrane (Table 1 and Figures 2-4). These findings have also highlighted the occurrence of differences in the function of nuclear GPCRs towards plasma membrane GPCRs.

It is conceivable that some of the clinical effects attributed so far to the GPCR-based drugs already in the market (that have been considered to act solely on the plasma membrane GPCRs) can be ascribed, at least in part, to the activation or blockage of GPCRs localized in the nuclear membrane. For example, $\mathrm{AT}_{1}$ receptor antagonists such as Losartan, in use in the clinical practice to treat hypertension, can promote vasodilation of smooth muscle cells (diminishing blood pressure), an effect that has been attributed to plasma membrane $\mathrm{AT}_{1}$ receptors blockade, but in agreement with data recent described may also address an additional mechanism of action involving the $\mathrm{AT}_{1}$ receptors localized in the nuclear membrane [31,90]: nuclear $\mathrm{AT}_{1}$ receptors when blocked reduced oxidative stress and $\mathrm{Ca}^{2+}$ generation, both effects also influencing vasodilation.

The same rationale can be applied to other GPCR-based drugs used in clinical practice to treat non-communicable diseases. For instance, Isoprenaline or Salmeterol, both $\beta$ adrenoceptor agonists, in use to treat arrhythmias and asthma, respectively. Another 
example is Montelukast, a $\mathrm{CysLT}_{1}$-selective antagonist, in use to treat asthma. These drugs act on GPCRs that have been reported in the plasma membrane but that recently have also been identified in the nuclear membrane and, these later receptors (nuclear GPCRs) may address, at least in part, their clinical efficacy (if we consider that nuclear GPCRs may reinforce the effects mediated by plasma membrane GPCRs).

In this sense, the occurrence in the nuclear membrane of receptors belonging to the renin angiotensin system (RAS), such as nuclear $\mathrm{AT}_{1}$ and nuclear $\mathrm{AT}_{2}$ receptors, already identified in cells from cardiovascular and nervous systems (see Table 1), highlight the possibility that these receptors may also be involved in the regulation of biological processes mediated by other players of RAS: it has been demonstrated that increased activation of plasma membrane $\mathrm{AT}_{1}$ receptors by Ang II triggers ERK1/2 and p38 MAPK signaling pathways, which causes a downregulation of angiotensin converting enzyme type 2 (ACE2) expression and, by opposition, an upregulation of angiotensin converting enzyme type 1 (ACE) [102]. Taking this into account, the eventuality that $\mathrm{AT}_{1}$ or $\mathrm{AT}_{2}$ localized in the nuclear membrane may also participate in the regulation of ACE and of ACE2 expressions should be put forward. It is also conceivable that effects mediated by nuclear GPCRs could block the initial responses triggered by plasma membrane GPCRs activation. In both cases, nuclear GPCRs would have a major impact on the pharmacological outcome and, consequently, in the therapy.

Since redistribution of GPCRs has been reported (Table 2) and can occur in healthy conditions as well as in diseases (and may differ depending on the progression of the disease), a GPCR ligand may exert effects that depend on the level of expression and/or distribution profile of GPCRs (as targets) localized in the nuclear versus plasma membrane. As so, the activation of the nuclear GPCRs may trigger responses conditioning the therapeutic outcome. In fact, nuclear receptors mediated actions can be distinct from those elicited by its respective plasma membrane counterparts. Furthermore, it is also plausible that some of the nuclear GPCR-mediated mechanisms might explain some side effects or unusual effects ascribed to some drugs in the clinical practice (for examples please see [27]).

Despite most of the nuclear GPCRs and plasma membrane GPCRs have identical structures, some exceptions have been reported: in frizzled-2 (FZD2) receptor, only a small functional portion of the heptahelical chain, without the C-terminus, seem to be translocated into the nuclear membrane [103]; GPCRs might undergo post-translational modifications that differ between the plasma and nuclear membranes [49], as occurs for the endothelin type $\mathrm{B}\left(\mathrm{ET}_{\mathrm{B}}\right)$ receptor since only the plasma membrane receptor undergoes $\mathrm{N}$-glycosylation, while in nuclear $\mathrm{ET}_{\mathrm{B}}$, receptor N-glycosylation is absent [104]. Another major structural feature that has an impact on GPCRs responses relies on plasma membrane lipid composition and/or structure and their respective influence on GPCR conformation $[61,105,106]$. To our knowledge, at present, there is no information in the literature regarding the influence of lipid composition on nuclear GPCRs dynamics, but it has been observed that lipid partitioning controls membrane biogenesis at the nuclear envelope [107] suggesting that nuclear lipid composition or structure can be modified. In addition, some studies have indicated that lipid composition influences nuclear receptors' function such as androgen receptors, glucocorticoid receptors, among others [105,108]. Additionally, the occurrence of nuclear microdomains lipid composition has been described to change according to cell status, being increased, for instance, in cell proliferation $[109,110]$. Thus, altogether these features appoint for the possibility that altered nuclear GPCR activities result, at least in part, from modified lipid composition and structure of the nuclear membrane, which would influence the access of ligands to nuclear GPCRs but also modify nuclear GPCR self-responses to ligands, thus conditioning the therapeutic outcomes. This possibility needs to be explored in future studies to provide new insights on the mechanisms of nuclear GPCR altered functions and/or expressions. 


\section{Conclusions}

In recent years nuclear GPCRs have evidenced important physiological roles, namely in the regulation of cell proliferation, transcription, apoptosis, angiogenesis and cell survival. In multiple pathological conditions such as non-communicable diseases (cancer, neurological and neurodegenerative diseases as well as cardiovascular diseases), changes in nuclear GPCRs have been described, namely with the occurrence of modified expressions and/or of atypical and/or disruptive signaling pathways (triggered by nuclear GPCRs) which highlight nuclear GPCRs as promising therapeutic targets. Future studies are required to better understand the new intracellular roles of GPCRs including the selectivity and/or affinity of tailor ligands for both nuclear and plasma membrane GPCRs, contributing, therefore, to improve GPCR-based therapeutics to non-communicable diseases.

Author Contributions: Conceptualization: C.D., M.V., S.G.-M., R.R.-O., J.B.S., M.S.V.-R.; writingoriginal draft preparation, C.D., M.V., S.G.-M., R.R.-O., J.B.S., M.S.V.-R.; writing-review and editing, C.D., M.V., R.R.-O., J.B.S., M.S.V.-R.; supervision, C.D.; funding acquisition, C.D. All authors have read and agreed to the published version of the manuscript.

Funding: FCT is acknowledged for UIDB 50006/2020 with funding from FCT/MCTES through national funds.

Acknowledgments: Martin Vojtek thanks Portuguese Foundation for Science and Technology (FCT) and PhD Program in Medicines and Pharmaceutical Innovation (i3DU) for the PhD Grant $\mathrm{PD} / \mathrm{BD} / 135460 / 2017$ funded by the European Social Fund of the European Union and national funds FCT/MCTES. Rita Ribeiro-Oliveira thanks the Portuguese Foundation for Science and Technology for the Ph.D. grant SFRH/BD/146243/2019, funded by the European Social Fund of the European Union and national funds FCT/MCTES through the Norte's Regional Operational Programme.

Conflicts of Interest: Authors declare no conflict of interest.

\section{References}

1. Sriram, K.; Insel, P.A. G protein-coupled receptors as targets for approved drugs: How many targets and how many drugs? Mol. Pharmacol. 2018, 93, 251-258. [CrossRef] [PubMed]

2. Wang, W.; Qiao, Y.; Li, Z. New Insights into Modes of GPCR Activation. Trends Pharmacol. Sci. 2018, 39, 367-386. [CrossRef]

3. Zhao, J.; Deng, Y.; Jiang, Z.; Qing, H. G protein-coupled receptors (GPCRs) in Alzheimer's disease: A focus on BACE1 related GPCRs. Front. Aging Neurosci. 2016, 8, 58. [CrossRef] [PubMed]

4. Yim, Y.Y.; Zurawski, Z.; Hamm, H. GPCR regulation of secretion. Pharmacol. Ther. 2018, 192, 124-140. [CrossRef] [PubMed]

5. Di Pizio, A.; Behrens, M.; Krautwurst, D. Beyond the flavour: The potential druggability of chemosensory G protein-coupled receptors. Int. J. Mol. Sci. 2019, 20, 1402. [CrossRef]

6. Cong, X.; Ren, W.; Pacalon, J.; de March, C.A.; Xu, L.; Matsunami, H.; Yu, Y.; Golebiowski, J. Functions of olfactory receptors are decoded from their sequence. bioRxiv 2020, 10-16. [CrossRef]

7. Ahmad, R.; Dalziel, J.E. G Protein-Coupled Receptors in Taste Physiology and Pharmacology. Front. Pharmacol. 2020, 11, 587664. [CrossRef]

8. Birch, G.G. Modulation of sweet taste. BioFactors 1999, 9, 73-80. [CrossRef]

9. Tyndall, J.; Sandilya, R. GPCR Agonists and Antagonists in the Clinic. Med. Chem. 2005, 1, 405-421. [CrossRef] [PubMed]

10. Weis, W.I.; Kobilka, B.K. The Molecular Basis of G Protein-Coupled Receptor Activation Keywords. Ann. Rev. Biochem. 2018, 87, 897-919. [CrossRef]

11. Alexander, S.P.H.; Christopoulos, A.; Davenport, A.P.; Kelly, E.; Mathie, A.; Peters, J.A.; Veale, E.L.; Armstrong, J.F.; Faccenda, E.; Harding, S.D.; et al. THE CONCISE GUIDE TO PHARMACOLOGY 2019/20: G protein-coupled receptors. Br. J. Pharmacol. 2019, 176, S21-S141. [CrossRef]

12. Yang, D.; Zhou, Q.; Labroska, V.; Qin, S.; Darbalaei, S.; Wu, Y.; Yuliantie, E.; Xie, L.; Tao, H.; Cheng, J.; et al. G protein-coupled receptors: Structure- and function-based drug discovery. Signal Transduct. Target. Ther. 2021, 6, 7. [CrossRef]

13. Peralta-Yahya, P.; Mukherjee, K.; Bhattacharyya, S.; Sarria, S. G-Protein Coupled Receptor (gpcr)-Based Biosensors and Uses Thereof. US 2016/0122832 A1. Available online: http:/ /hdl.handle.net/1853/59617 (accessed on 5 May 2016).

14. Vavitsas, K. Turning G protein-coupled receptors into tunable biosensors. Synth. Biol. 2019, 4, ysz011. [CrossRef]

15. Haider, R.S.; Godbole, A.; Hoffmann, C. To sense or not to sense-new insights from GPCR-based and arrestin-based biosensors. Curr. Opin. Cell Biol. 2019, 57, 16-24. [CrossRef] [PubMed]

16. Topiol, S. Current and Future Challenges in GPCR Drug Discovery. In Computational Methods for GPCR Drug Discovery; Heifetz, A., Ed.; Humana Press Inc.: New York, NY, USA, 2018; pp. 1-21. 
17. Clinical Trials.Gov. Available online: https: / clinicaltrials.gov $/$ ct $2 /$ results? cond=\&term $=$ gpcr\&cntry=\&state=\&city=\&dist= (accessed on 21 January 2021).

18. Lappano, R.; Maggiolini, M. Pharmacotherapeutic Targeting of G Protein-Coupled Receptors in Oncology: Examples of Approved Therapies and Emerging Concepts. Drugs 2017, 77, 951-965. [CrossRef] [PubMed]

19. Audet, N.; Dabouz, R.; Allen, B.G.; Hébert, T.E. Nucleoligands-repurposing G Protein-coupled Receptor Ligands to Modulate Nuclear-localized G Protein-coupled Receptors in the Cardiovascular System. J. Cardiovasc. Pharmacol. 2018, 71, 193-204. [CrossRef] [PubMed]

20. Wacker, D.; Stevens, R.C.; Roth, B.L. How Ligands Illuminate GPCR Molecular Pharmacology. Cell 2017, 170, 414-427. [CrossRef]

21. Syrovatkina, V.; Alegre, K.O.; Dey, R.; Huang, X.Y. Regulation, Signaling, and Physiological Functions of G-Proteins. J. Mol. Biol. 2016, 428, 3850-3868. [CrossRef]

22. Martin, R.D.; Bouazza, C.A.; Hébert, T.E. Organellar G $\beta \gamma$ signaling-GPCR signaling beyond the cell surface. In GPCRs; Jastrzebska, B., Park, P.S.-H., Eds.; Elsevier: Amsterdam, The Netherlands, 2020; pp. 257-267.

23. Ranjan, R.; Dwivedi, H.; Baidya, M.; Kumar, M.; Shukla, A.K. Novel Structural Insights into GPCR- $\beta$-Arrestin Interaction and Signaling. Trends Cell Biol. 2017, 27, 851-862. [CrossRef]

24. Robertson, A.L.; Khairallah, P.A. Angiotensin II: Rapid Localization in Nuclei of Smooth and Cardiac Muscle. Science 1971, 172, 1138-1139. [CrossRef] [PubMed]

25. Suofu, Y.; Li, W.; Jean-Alphonse, F.G.; Jia, J.; Khattar, N.K.; Li, J.; Baranov, S.V.; Leronni, D.; Mihalik, A.C.; He, Y.; et al. Dual role of mitochondria in producing melatonin and driving GPCR signaling to block cytochrome c release. Proc. Natl. Acad. Sci. USA 2017, 114, E7997-E8006. [CrossRef] [PubMed]

26. Smith, N.J.; Mouat, M.A.; Coleman, J.L.J. GPCRs in context: Sexual dimorphism in the cardiovascular system. Br. J. Pharmacol. 2018, 175, 4047.

27. Ribeiro-Oliveira, R.; Vojtek, M.; Gonçalves-Monteiro, S.; Vieira-Rocha, M.S.; Sousa, J.B.; Gonçalves, J.; Diniz, C. Nuclear G-proteincoupled receptors as putative novel pharmacological targets. Drug Discov. Today 2019, 24, 2192-2201. [CrossRef]

28. Eichel, K.; von Zastrow, M. Subcellular Organization of GPCR Signaling. Trends Pharmacol. Sci. 2018, 39, 200-208. [CrossRef] [PubMed]

29. Bkaily, G.; Al-Khoury, J.; Jacques, D. Nuclear membranes GPCRs: Implication in cardiovascular health and diseases. Curr. Vasc. Pharmacol. 2014, 12, 215-222. [CrossRef]

30. Tadevosyan, A.; Vaniotis, G.; Allen, B.G.; Hébert, T.E.; Nattel, S. G protein-coupled receptor signalling in the cardiac nuclear membrane: Evidence and possible roles in physiological and pathophysiological function. J. Physiol. 2012, 590, 1313-1330. [CrossRef]

31. Tadevosyan, A.; Xiao, J.; Surinkaew, S.; Naud, P.; Merlen, C.; Harada, M.; Qi, X.; Chatenet, D.; Fournier, A.; Allen, B.G.; et al. Intracellular Angiotensin-II Interacts With Nuclear Angiotensin Receptors in Cardiac Fibroblasts and Regulates RNA Synthesis, Cell Proliferation, and Collagen Secretion. J. Am. Heart Assoc. 2017, 6, e004965. [CrossRef]

32. Sergin, I.; Jong, Y.J.I.; Harmon, S.K.; Kumar, V.; O'Malley, K.L. Sequences within the C terminus of the metabotropic glutamate receptor 5 (mGluR5) are responsible for inner nuclear membrane localization. J. Biol. Chem. 2017, 292, 3637-3655. [CrossRef]

33. Foster, S.R.; Bräuner-Osborne, H. Investigating internalization and intracellular trafficking of GPCRs: New techniques and real-time experimental approaches. In Handbook of Experimental Pharmacology; Springer: New York, NY, USA, 2018; Volume 245, pp. 41-61.

34. Bhosle, V.K.; Rivera, J.C.; Chemtob, S. New insights into mechanisms of nuclear translocation of G-protein coupled receptors. Small GTPases 2019, 10, 254-263. [CrossRef] [PubMed]

35. Cattaneo, F.; Parisi, M.; Fioretti, T.; Sarnataro, D.; Esposio, G.; Ammendola, R. Nuclear localization of Formyl-Peptide Receptor 2 in human cancer cells. Arch. Biochem. Biophys. 2016, 603, 10-19. [CrossRef]

36. Pickard, B.W.; Hodsman, A.B.; Fraher, L.J.; Watson, P.H. Type 1 parathyroid hormone receptor (PTH1R) nuclear trafficking: Regulation of PTH1R nuclear-cytoplasmic shuttling by importin- $\alpha / \beta$ and chromosomal region maintenance $1 /$ exportin 1 . Endocrinology 2007, 148, 2282-2289. [CrossRef] [PubMed]

37. Jong, Y.-J.I.; Harmon, S.K.; O’Malley, K.L. GPCR signalling from within the cell. Br. J. Pharmacol. 2018, 175, 4026-4035. [CrossRef]

38. Nielsen, C.K.; Campbell, J.I.A.; Ohd, J.F.; Morgelin, M.; Riesbeck, K.; Landberg, G.; Sjolander, A. A Novel Localization of the G-Protein-Coupled CysLT 1 Receptor in the Nucleus of Colorectal Adenocarcinoma Cells. Cancer Res. 2005, 65, 732-742. [PubMed]

39. Cattaneo, F.; Parisi, M.; Fioretti, T.; Esposito, G.; Ammendola, R. Intranuclear Signaling Cascades Triggered by Nuclear GPCRs. J. Cell Signal 2016, 1, 1000128-1. [CrossRef]

40. Lucero, H.A.; Kintsurashvili, E.; Marketou, M.E.; Gavras, H. Cell signaling, internalization, and nuclear localization of the angiotensin converting enzyme in smooth muscle and endothelial cells. J. Biol. Chem. 2010, 285, 5555-5568. [CrossRef]

41. Mir, F.; Le Breton, G.C. A Novel Nuclear Signaling Pathway for Thromboxane A2 Receptors in Oligodendrocytes: Evidence for Signaling Compartmentalization during Differentiation. Mol. Cell. Biol. 2008, 28, 6329-6341. [CrossRef] [PubMed]

42. Zhu, T.; Gobeil, F.; Vazquez-Tello, G.; Leduc, M.; Rihakova, L.; Bossolasco, M.; Bkaily, G.; Peri, K.; Varma, D.R.; Orvoine, R.; et al. Intracrine signaling through lipid mediators and their cognate nuclear G-protein-coupled receptors: A paradigm based on PGE2, PAF, and LPA1 receptors. Can. J. Physiol. Pharmacol. 2006, 84, 377-391. [CrossRef]

43. Jafri, F.; Ergul, A. Nuclear Localization of Endothelin-Converting Enzyme-1: Subisoform Specificity. Arterioscler. Thromb. Vasc. Biol. 2003, 23, 2192-2196. [CrossRef] [PubMed] 
44. Doan, N.D.; Nguyen, T.T.M.; Létourneau, M.; Turcotte, K.; Fournier, A.; Chatenet, D. Biochemical and pharmacological characterization of nuclear urotensin-II binding sites in rat heart. Br. J. Pharmacol. 2012, 166, 243-257. [CrossRef]

45. Villar-Cheda, B.; Costa-Besada, M.A.; Valenzuela, R.; Perez-Costas, E.; Melendez-Ferro, M.; Labandeira-Garcia, J.L. The intracellular angiotensin system buffers deleterious effects of the extracellular paracrine system. Cell Death Dis. 2017, 8, e3044. [CrossRef] [PubMed]

46. Pendergrass, K.D.; Gwathmey, T.Y.M.; Michalek, R.D.; Grayson, J.M.; Chappell, M.C. The angiotensin II-AT1 receptor stimulates reactive oxygen species within the cell nucleus. Biochem. Biophys. Res. Commun. 2009, 384, 149-154. [CrossRef]

47. Cook, J.L.; Zhang, Z.; Re, R.N. In vitro evidence for an intracellular site of angiotensin action. Circ. Res. 2001, 89, 1138-1146. [CrossRef] [PubMed]

48. Boivin, B.; Lavoie, C.; Vaniotis, G.; Baragli, A.; Villeneuve, L.R.; Ethier, N.; Trieu, P.; Allen, B.G.; Hébert, T.E. Functional $\beta$ adrenergic receptor signalling on nuclear membranes in adult rat and mouse ventricular cardiomyocytes. Cardiovasc. Res. 2006, 71, 69-78. [CrossRef] [PubMed]

49. Nguyen, T.T.M.; Létourneau, M.; Chatenet, D.; Fournier, A. Presence of urotensin-II receptors at the cell nucleus: Specific tissue distribution and hypoxia-induced modulation. Int. J. Biochem. Cell Biol. 2012, 44, 639-647. [CrossRef]

50. Savard, M.; Barbaz, D.; Bélanger, S.; Müller-Esterl, W.; Bkaily, G.; D’Orléans-Juste, P.; Coté, J.; Bovenzi, V.; Gobeil, F. Expression of endogenous nuclear bradykinin B2 receptors mediating signaling in immediate early gene activation. J. Cell. Physiol. 2008, 216, 234-244. [CrossRef]

51. Tadevosyan, A.; Villeneuve, L.R.; Fournier, A.; Chatenet, D.; Nattel, S.; Allen, B.G. Caged ligands to study the role of intracellular GPCRs. Methods 2016, 92, 72-77. [CrossRef]

52. Chan, H.C.S.; Li, Y.; Dahoun, T.; Vogel, H.; Yuan, S. New Binding Sites, New Opportunities for GPCR Drug Discovery. Trends Biochem. Sci. 2019, 44, 312-330. [CrossRef] [PubMed]

53. Cohen, O.; Granek, R. Nucleus-targeted drug delivery: Theoretical optimization of nanoparticles decoration for enhanced intracellular active transport. Nano Lett. 2014, 14, 2515-2521. [CrossRef]

54. Wang, F.; Wang, Y.; Zhang, X.; Zhang, W.; Guo, S.; Jin, F. Recent progress of cell-penetrating peptides as new carriers for intracellular cargo delivery. J. Control. Release 2014, 174, 126-136. [CrossRef]

55. Davenport, A.P.; Scully, C.C.G.; de Graaf, C.; Brown, A.J.H.; Maguire, J.J. Advances in therapeutic peptides targeting G proteincoupled receptors. Nat. Rev. Drug Discov. 2020, 19, 389-413. [CrossRef]

56. Woodman, S.; Trousdale, C.; Conover, J.; Kim, K. Yeast membrane lipid imbalance leads to trafficking defects toward the Golgi. Cell Biol. Int. 2018, 42, 890-902. [CrossRef] [PubMed]

57. Casares, D.; Escribá, P.V.; Rosselló, C.A. Membrane lipid composition: Effect on membrane and organelle structure, function and compartmentalization and therapeutic avenues. Int. J. Mol. Sci. 2019, 20, 2167. [CrossRef] [PubMed]

58. Lazzarini, A.; Macchiarulo, A.; Floridi, A.; Coletti, A.; Cataldi, S.; Codini, M.; Lazzarini, R.; Bartoccini, E.; Cascianelli, G.; Ambesi-Impiombato, F.S.; et al. Very long chain fatty acid sphingomyelin in nuclear lipid microdomains of hepatocytes and hepatoma cells: Can the exchange from C24:0 to C16:0 affect signal proteins and vitamin D receptor? Mol. Biol. Cell 2015, 26, 2418-2425. [CrossRef]

59. Bruzzese, A.; Gil, C.; Dalton, J.A.R.; Giraldo, J. Structural insights into positive and negative allosteric regulation of a G protein-coupled receptor through protein-lipid interactions. Sci. Rep. 2018, 8, 4456. [CrossRef] [PubMed]

60. Alemany, R.; Perona, J.S.; Sánchez-Dominguez, J.M.; Montero, E.; Cañizares, J.; Bressani, R.; Escribá, P.V.; Ruiz-Gutierrez, V. G protein-coupled receptor systems and their lipid environment in health disorders during aging. Biochim. Biophys. Acta-Biomembr. 2007, 1768, 964-975. [CrossRef] [PubMed]

61. Mizuno, H.; Kihara, Y. Druggable Lipid GPCRs: Past, Present, and Prospects. In Druggable Lipid Signaling Pathways; Kihara, Y., Ed.; Springer Nature: Cham, Switzerland, 2020; pp. 223-258.

62. Tao, Y.X. Constitutive activation of G protein-coupled receptors and diseases: Insights into mechanisms of activation and therapeutics. Pharmacol. Ther. 2008, 120, 129-148. [CrossRef]

63. Schöneberg, T.; Liebscher, I. Mutations in G Protein-Coupled Receptors: Mechanisms, Pathophysiology and Potential Therapeutic Approaches. Pharmacol. Rev. 2021, 73, 89-119. [CrossRef]

64. Insel, P.A.; Sriram, K.; Wiley, S.Z.; Wilderman, A.; Katakia, T.; McCann, T.; Yokouchi, H.; Zhang, L.; Corriden, R.; Liu, D.; et al. GPCRomics: GPCR expression in cancer cells and tumors identifies new, potential biomarkers and therapeutic targets. Front. Pharmacol. 2018, 9, 431. [CrossRef]

65. Wald, O. CXCR4 Based Therapeutics for Non-Small Cell Lung Cancer (NSCLC). J. Clin. Med. 2018, 7, 303. [CrossRef] [PubMed]

66. Spano, J.P.; Andre, F.; Morat, L.; Sabatier, L.; Besse, B.; Combadiere, C.; Deterre, P.; Martin, A.; Azorin, J.; Valeyre, D.; et al. Chemokine receptor CXCR4 and early-stage non-small cell lung cancer: Pattern of expression and correlation with outcome. Ann. Oncol. 2004, 15, 613-617. [CrossRef] [PubMed]

67. Na, I.K.; Scheibenbogen, C.; Adam, C.; Stroux, A.; Ghadjar, P.; Thiel, E.; Keilholz, U.; Coupland, S.E. Nuclear expression of CXCR4 in tumor cells of non-small cell lung cancer is correlated with lymph node metastasis. Hum. Pathol. 2008, 39, 1751-1755. [CrossRef]

68. Shibuta, K.; Mori, M.; Shimoda, K.; Inoue, H.; Mitra, P.; Barnard, G.F. Regional Expression of CXCL12/CXCR4 in Liver and Hepatocellular Carcinoma and Cell-cycle Variation during in vitro Differentiation. Jpn. J. Cancer Res. 2002, 93, 789-797. [CrossRef] 
69. Gobeil, F.; Bernier, S.G.; Vazquez-Tello, A.; Brault, S.; Beauchamp, M.H.; Quiniou, C.; Marrache, A.M.; Checchin, D.; Sennlaub, F.; Hou, X.; et al. Modulation of pro-inflammatory gene expression by nuclear lysophosphatidic acid receptor type-1. J. Biol. Chem. 2003, 278, 38875-38883. [CrossRef] [PubMed]

70. Don-Salu-Hewage, A.S.; Chan, S.Y.; McAndrews, K.M.; Chetram, M.A.; Dawson, M.R.; Bethea, D.A.; Hinton, C.V. Cysteine (C)-XC Receptor 4 Undergoes Transportin 1-Dependent Nuclear Localization and Remains Functional at the Nucleus of Metastatic Prostate Cancer Cells. PLoS ONE 2013, 8, e57194. [CrossRef] [PubMed]

71. Patel, N.; Itakura, T.; Jeong, S.; Liao, C.P.; Roy-Burman, P.; Zandi, E.; Groshen, S.; Pinski, J.; Coetzee, G.A.; Gross, M.E.; et al. Expression and functional role of orphan receptor GPR158 in prostate cancer growth and progression. PLoS ONE 2015, 10, e0117758. [CrossRef]

72. Wang, N.; Wu, Q.L.; Fang, Y.; Mai, H.Q.; Zeng, S.; Shen, G.P.; Hou, J.H.; Zeng, Y.X. Expression of chemokine receptor CXCR4 in nasopharyngeal carcinoma: Pattern of expression and correlation with clinical outcome. J. Transl. Med. 2005, 3, 26. [CrossRef]

73. Speetjens, F.M.; Liefers, G.J.; Korbee, C.J.; Mesker, W.E.; Van De Velde, C.J.H.; Van Vlierberghe, R.L.; Morreau, H.; Tollenaar, R.A.; Kuppen, P.J.K. Nuclear localization of CXCR4 determines prognosis for colorectal cancer patients. Cancer Microenviron. 2009, 2, 1-7. [CrossRef] [PubMed]

74. Yoshitake, N.; Fukui, H.; Yamagishi, H.; Sekikawa, A.; Fujii, S.; Tomita, S.; Ichikawa, K.; Imura, J.; Hiraishi, H.; Fujimori, T. Expression of SDF- $1 \alpha$ and nuclear CXCR4 predicts lymph node metastasis in colorectal cancer. Br. J. Cancer 2008, 98, 1682-1689. [CrossRef]

75. Lanoix, D.; Ouellette, R.; Vaillancourt, C. Expression of melatoninergic receptors in human placental choriocarcinoma cell lines. Hum. Reprod. 2006, 21, 1981-1989. [CrossRef]

76. Kinsey, C.G.; Bussolati, G.; Bosco, M.; Kimura, T.; Pizzorno, M.C.; Chernin, M.I.; Cassoni, P.; Novak, J.F. Constitutive and ligand-induced nuclear localization of oxytocin receptor. J. Cell. Mol. Med. 2007, 11, 96-110. [CrossRef] [PubMed]

77. Valdehita, A.; Bajo, A.M.; Fernández-Martínez, A.B.; Arenas, M.I.; Vacas, E.; Valenzuela, P.; Ruíz-Villaespesa, A.; Prieto, J.C.; Carmena, M.J. Nuclear localization of vasoactive intestinal peptide (VIP) receptors in human breast cancer. Peptides 2010, 31, 2035-2045. [CrossRef]

78. Xu, Z.; Li, P.; Wei, D.; Wang, Z.; Bao, Y.; Sun, J.; Qu, L.; Wang, L. NMMHC-IIA-dependent nuclear location of CXCR4 promotes migration and invasion in renal cell carcinoma. Oncol. Rep. 2016, 36, 2681-2688. [CrossRef] [PubMed]

79. Dubuc, C.; Savard, M.; Bovenzi, V.; Lessard, A.; Côté, J.; Neugebauer, W.; Geha, S.; Chemtob, S.; Gobeil, F. Antitumor activity of cell-penetrant kinin B1 receptor antagonists in human triple-negative breast cancer cells. J. Cell. Physiol. 2019, 234, $2851-2865$. [CrossRef] [PubMed]

80. Dubuc, C.; Savard, M.; Bovenzi, V.; Lessard, A.; Fortier, A.; Côté, J.; Neugebauer, W.; Rizzolio, F.; Geha, S.; Giordano, A.; et al. Targeting intracellular B2 receptors using novel cell-penetrating antagonists to arrest growth and induce apoptosis in human triple-negative breast cancer. Oncotarget 2018, 9, 9885-9906. [CrossRef] [PubMed]

81. Stevenson, C.B.; Ehtesham, M.; McMillan, K.M.; Valadez, J.G.; Edgeworth, M.L.; Price, R.R.; Abel, T.W.; Mapara, K.Y.; Thompson, R.C. CXCR4 expression is elevated in glioblastoma multiforme and correlates with an increase in intensity and extent of peritumoral T2-weighted magnetic resonance imaging signal abnormalities. Neurosurgery 2008, 63, 560-569. [CrossRef] [PubMed]

82. Barbarin, A.; Séité, P.; Godet, J.; Bensalma, S.; Muller, J.M.; Chadéneau, C. Atypical nuclear localization of VIP receptors in glioma cell lines and patients. Biochem. Biophys. Res. Commun. 2014, 454, 524-530. [CrossRef] [PubMed]

83. Nikkhoo, B.; Jalili, A.; Fakhari, S.; Sheikhesmaili, F.; Fathi, F.; Rooshani, D.; Hoseinpour Feizi, M.A.; Nikzaban, M. Nuclear pattern of CXCR4 expression is associated with a better overall survival in patients with gastric cancer. J. Oncol. 2014, 1, 808012. [CrossRef] [PubMed]

84. Masuda, T.; Nakashima, Y.; Ando, K.; Yoshinaga, K. Nuclear Expression of Chemokine Receptor CXCR4 Indicates Poorer Prognosis in Gastric Cancer. Anticancer Res. 2014, 6404, 6397-6403.

85. Wang, L.; Wang, Z.; Yang, B.; Yang, Q.; Wang, L.; Sun, Y. CXCR4 nuclear localization follows binding of its ligand SDF-1 and occurs in metastatic but not primary renal cell carcinoma. Oncol. Rep. 2009, 22, 1333-1339. [PubMed]

86. Bao, Y.; Wang, Z.; Liu, B.; Lu, X.; Xiong, Y.; Shi, J.; Li, P.; Chen, J.; Zhang, Z.; Chen, M.; et al. A feed-forward loop between nuclear translocation of CXCR4 and HIF-1 $\alpha$ promotes renal cell carcinoma metastasis. Oncogene 2019, 38, 881-895. [CrossRef]

87. Wang, L.; Chen, W.; Gao, L.; Yang, Q.; Liu, B.; Wu, Z.; Wang, Y.; Sun, Y. High expression of CXCR4, CXCR7 and SDF-1 predicts poor survival in renal cell carcinoma. World J. Surg. Oncol. 2012, 10, 212. [CrossRef] [PubMed]

88. Vaniotis, G.; Del Duca, D.; Trieu, P.; Rohlicek, C.V.; Hébert, T.E.; Allen, B.G. Nuclear $\beta$-adrenergic receptors modulate gene expression in adult rat heart. Cell. Signal. 2011, 23, 89-98. [CrossRef] [PubMed]

89. Pendergrass, K.D.; Averill, D.B.; Ferrario, C.M.; Diz, D.I.; Chappell, M.C. Differential expression of nuclear AT 1 receptors and angiotensin II within the kidney of the male congenic mRen2.Lewis rat. Am. J. Physiol Ren. Physiol. 2006, 290, 1497-1506. [CrossRef]

90. Gwathmey, T.M.; Shaltout, H.A.; Rose, J.C.; Diz, D.I.; Chappell, M.C. Glucocorticoid-induced fetal programming alters the functional complement of angiotensin receptor subtypes within the kidney. Hypertension 2011, 57, 620-626. [CrossRef]

91. Estrada, R.; Wang, L.; Jala, V.R.; Lee, J.F.; Lin, C.Y.; Gray, R.D.; Haribabu, B.; Lee, M.J. Ligand-induced nuclear translocation of S1P1 receptors mediates Cyr61 and CTGF transcription in endothelial cells. Histochem. Cell Biol. 2009, 131, 239-249. [CrossRef] [PubMed]

92. Zhang, H.; Yang, Y.; Takeda, A.; Yoshimura, T.; Oshima, Y.; Sonoda, K.H.; Ishibashi, T. A Novel Platelet-Activating Factor Receptor Antagonist Inhibits Choroidal Neovascularization and Subretinal Fibrosis. PLoS ONE 2013, 8, e68173. [CrossRef] 
93. Joyal, J.-S.; Nim, S.; Zhu, T.; Sitaras, N.; Rivera, J.C.; Shao, Z.; Sapieha, P.; Hamel, D.; Sanchez, M.; Zaniolo, K.; et al. Subcellular localization of coagulation factor II receptor-like 1 in neurons governs angiogenesis. Nat. Med. 2014, 20, 1165-1173. [CrossRef] [PubMed]

94. Vincent, K.; Cornea, V.M.; Jong, Y.J.I.; Laferriere, A.; Kumar, N.; Mickeviciute, A.; Fung, J.S.T.; Bandegi, P.; Ribeiro-Da-Silva, A.; O'Malley, K.L.; et al. Intracellular mGluR5 plays a critical role in neuropathic pain. Nat. Commun. 2016, 7, 10604. [CrossRef]

95. Vincent, K.; Wang, F.S.; Laferrière, A.; Kumar, N.; Coderre, T.J. Spinal intracellular metabotropic glutamate receptor 5 (mGluR5) contributes to pain and c-fos expression in a rat model of inflammatory pain. Pain 2017, 158, 705-716. [CrossRef]

96. Argañaraz, G.A.; Silva, J.A.; Perosa, S.R.; Pessoa, L.G.; Carvalho, F.F.; Bascands, J.L.; Bader, M.; Trindade, E.D.S.; Amado, D.; Cavalheiro, E.A.; et al. The synthesis and distribution of the kinin B1 and B2 receptors are modified in the hippocampus of rats submitted to pilocarpine model of epilepsy. Brain Res. 2004, 1006, 114-125. [CrossRef]

97. Xu, C.; Zhao, H.; Chen, H.; Yao, Q. CXCR4 in breast cancer: Oncogenic role and therapeutic targeting. Drug Des. Devel. Ther. 2015, 9, 4953-4964.

98. Kumar, V.; Fahey, P.G.; Jong, Y.J.I.; Ramanan, N.; O'Malley, K.L. Activation of intracellular metabotropic glutamate receptor 5 in striatal neurons leads to up-regulation of genes associated with sustained synaptic transmission including Arc/Arg3.1 protein. J. Biol. Chem. 2012, 287, 5412-5425. [CrossRef] [PubMed]

99. Liao, J.J.; Huang, M.C.; Graler, M.; Huang, Y.; Qiu, H.; Goetzl, E.J. Distinctive T cell-suppressive signals from nuclearized type 1 sphingosine 1-phosphate G protein-coupled receptors. J. Biol. Chem. 2007, 282, 1964-1972. [CrossRef]

100. Bassett, J.H.D.; Nordström, K.; Boyde, A.; Howell, P.G.T.; Kelly, S.; Vennström, B.; Williams, G.R. Thyroid status during skeletal development determines adult bone structure and mineralization. Mol. Endocrinol. 2007, 21, 1893-1904. [CrossRef] [PubMed]

101. Abiodun, O.A.; Ola, M.S. Role of brain renin angiotensin system in neurodegeneration: An update. Saudi J. Biol. Sci. 2020, 27, 905-912. [CrossRef]

102. Gheblawi, M.; Wang, K.; Viveiros, A.; Nguyen, Q.; Zhong, J.C.; Turner, A.J.; Raizada, M.K.; Grant, M.B.; Oudit, G.Y. AngiotensinConverting Enzyme 2: SARS-CoV-2 Receptor and Regulator of the Renin-Angiotensin System: Celebrating the 20th Anniversary of the Discovery of ACE2. Circ. Res. 2020, 126, 1456-1474. [CrossRef] [PubMed]

103. Mosca, T.J.; Schwarz, T.L. The nuclear import of Frizzled2-C by Importins- $\beta 211$ and $\hat{I} \pm 2$ promotes postsynaptic development. Nat. Neurosci. 2010, 13, 935-943. [CrossRef] [PubMed]

104. Merlen, C.; Farhat, N.; Luo, X.; Chatenet, D.; Tadevosyan, A.; Villeneuve, L.R.; Gillis, M.A.; Nattel, S.; Thorin, E.; Fournier, A.; et al. Intracrine endothelin signaling evokes IP3-dependent increases in nucleoplasmic Ca2+ in adult cardiac myocytes. J. Mol. Cell. Cardiol. 2013, 62, 189-202. [CrossRef]

105. Marino, K.A.; Prada-Gracia, D.; Provasi, D.; Filizola, M. Impact of Lipid Composition and Receptor Conformation on the Spatio-temporal Organization of $\mu$-Opioid Receptors in a Multi-component Plasma Membrane Model. PLoS Comput. Biol. 2016, 12, e1005240. [CrossRef]

106. Mahmood, M.; Liu, X.; Neya, S.; Hoshino, T. Influence of Lipid Composition on the Structural Stability of G-Protein Coupled Receptor. Chem. Pharm. Bull. 2013, 61, 426-437. [CrossRef]

107. Barbosa, A.D.; Sembongi, H.; Su, W.M.; Abreu, S.; Reggiori, F.; Carman, G.M.; Siniossoglou, S. Lipid partitioning at the nuclear envelope controls membrane biogenesis. Mol. Biol. Cell 2015, 26, 3641-3657. [CrossRef]

108. Harayama, T.; Riezman, H. Understanding the diversity of membrane lipid composition. Nat. Rev. Mol. Cell Biol. 2018, 19, 281-296. [CrossRef] [PubMed]

109. Cascianelli, G.; Villani, M.; Tosti, M.; Marini, F.; Bartoccini, E.; Magni, M.V.; Albi, E. Lipid Microdomains in Cell Nucleus. Mol. Biol. Cell 2008, 19, 5289-5295. [CrossRef] [PubMed]

110. Albi, E.; Villani, M. Nuclear lipid microdomains regulate cell function. Commun. Integr. Biol. 2009, 2, 23-24. [CrossRef] [PubMed] 